\title{
RESOURCE ORCHESTRATION IN INNOVATION ECOSYSTEMS: A COMPARATIVE STUDY BETWEEN INNOVATION ECOSYSTEMS AT DIFFERENT STAGES OF DEVELOPMENT
}

\author{
ORQUESTRAÇ̃̃O DE RECURSOS EM ECOSSISTEMAS DE INOVAÇÃO: UM ESTUDO \\ COMPARATIVO ENTRE ECOSSISTEMAS DE INOVAÇÃO EM DIFERENTES ESTÁGIOS DE \\ DESENVOLVIMENTO
}

ORQUESTACIÓN DE RECURSOS EN ECOSISTEMAS DE INNOVACIÓN: UN ESTUDIO COMPARATIVO ENTRE ECOSISTEMAS DE INNOVACIÓN EN DIFERENTES ETAPAS DE DESARROLLO

\author{
Bruno Anicet Bittencourt ${ }^{1}$ \\ Diego Alex Gazaro dos Santos ${ }^{2}$ \\ iD Julhete Mignoni ${ }^{3}$
}

Cite as - American Psychological Association (APA)

Bittencourt, B. A., Santos, D. A. G., \& Mignoni, J. (2021, Jan./Apr.). Resource orchestration in innovation ecosystems: a comparative study between innovation ecosystems at different stages of development.

International Journal of Innovation - IJI, São Paulo, 9(1), 108-130. https://doi.org/10.5585/iji.v9i1.18076.

\begin{abstract}
Objective of the study: The present study aimed to answer the following question: How are resources orchestrated to generate innovation in innovation ecosystems?

Methodology/Approach: An exploratory qualitative research was conducted through documentary analysis, non-participant observation, and in-depth interviews with actors from two Brazilian ecosystems in different stages of development: 4th District (emerging) and Porto Digital (growth).

Originality/Relevance: Innovation ecosystems can be understood as a set of resources that foster innovation. Current research suggests that even more important than resources is the articulation among them and the way they are orchestrated.

Main Results: It was found that resource pooling characterizes the transition moment from the emergency stage to the growth stage.

Theoretical/ Methodological Contribution: A direct relationship between resource orchestration and the stage of ecosystem development was identified.

Social/Management Contribution: The importance of the orchestration role, as well as the presence of an orchestrating actor, was emphasized, and a framework of analysis on the orchestration of resources in innovation ecosystems was proposed.
\end{abstract}

Keywords: Resource orchestration. Innovation ecosystems. Stages of development.

\footnotetext{
${ }^{1} \mathrm{PhD}$ in Business Management, Universidade do Vale do Rio dos Sinos - UNISINOS. Porto Alegre - RS. banicet@ unisinos.br

${ }^{2} \mathrm{PhD}$ Student in Business Management, Universidade Federal do Rio Grande do Sul - UFRGS. Porto Alegre - RS. diegogazaro@gmail.com

3 Master Student in Business Management, Universidade do Vale do Rio dos Sinos - UNISINOS. Porto Alegre - RS. julhetemignoni@ hotmail.com
} 


\section{Resumo}

Objetivo de estudo: $O$ presente estudo teve como objetivo principal responder a seguinte questão: como os recursos são orquestrados para gerar inovação em ecossistemas de inovação?

Metodologia / Abordagem: Realizou-se uma pesquisa qualitativa exploratória, através de análise documental, observação não participante e entrevistas em profundidade com atores de dois ecossistemas brasileiros em diferentes estágios de desenvolvimento: $4^{\circ}$ Distrito (emergente) e Porto Digital (crescimento).

Originalidade / Relevância: Os ecossistemas de inovação podem ser entendidos como um conjunto de recursos que fomentam a inovação. As pesquisas mais atuais sugerem que, ainda mais importante que os recursos, é a articulação entre eles e o modo como ocorre sua orquestração.

Resultados principais: Verificou-se que o agrupamento de recursos caracteriza o momento de transição do estágio de emergência para o de crescimento.

Contribuição Teórica / Metodológica: Identificou-se uma relação direta entre a orquestração de recursos e o estágio de desenvolvimento do ecossistema.

Contribuição Social / Gestão: Ressaltou-se a importância do papel da orquestração, bem como, da presença de um ator orquestrador, e foi proposto um framework de análise sobre a orquestração de recursos em ecossistemas de inovação.

Palavras chave: Orquestração de recursos. Ecossistemas de inovação. Estágios de desenvolvimento.

\section{Resumen}

Objetivo del estudio: Así, El presente estudio tuvo como objetivo dar respuesta a la siguiente pregunta: ¿cómo se orquestan los recursos para generar innovación en ecosistemas de innovación?

Metodología / Enfoque: Realizó una investigación exploratoria cualitativa, mediante análisis documental, observación no participante y entrevistas en profundidad a actores de dos ecosistemas brasileños en diferentes etapas de desarrollo: Distrito 4 (emergente) y Porto Digital (crecimiento).

Originalidad / Relevancia: Los ecosistemas de innovación pueden entenderse como un conjunto de recursos que fomentan la innovación. La investigación más actual sugiere que, incluso más importante que los recursos, es la articulación entre ellos y la forma en que ocurre su orquestación.

Resultados principales: Se encontró que la agrupación de recursos caracteriza el momento de transición de la emergencia a la etapa de crecimiento.

Contribución teórica / metodológica: Se identificó una relación directa entre la orquestación de recursos y la etapa de desarrollo del ecosistema.

Contribución social / de gestión: Se enfatizó la importancia del rol de la orquestación, así como la presencia de un actor orquestador, y se propuso un marco de análisis sobre la orquestación de recursos en ecosistemas de innovación.

Palabras-clave: Orquestación de recursos. Ecosistemas de innovación. Etapas de desarrollo.

\section{Introduction}

The importance of inter-organizational relationships and networks is widely acknowledged (Valkokari et al, 2017). In recent years, innovation has evolved beyond the boundaries of single firms towards a more network-based approach (Choi et al., 2010; Ramadani et al., 2013, Cinelli, Ferraro \& Iovanella, 2019). With the complexity of those relations, it becomes necessary to understand which is the best model of management (Lumineau \& Oliveira, 2018; Majchrzak et al., 2015). It is understood that managing and assuring any process of innovation is a multifaceted and complex task (Pikkarainen et al, 2017), 
even more in environments where the actors are diverse and numerous (Reypens, Lievens \& Blazevic, 2019). Thus, the orchestration approach is probably the most suitable to describe development, management and coordination activities of the networks (Dhanaraj \& Parkhe, 2006; Ritala et al., 2009).

Among business networks, so-called innovation ecosystems have emerged promisingly in the literature about strategy, innovation and entrepreneurship. Innovation ecosystems can be understood as a network of interconnected and interrelated actors (Gomes et al., 2016), who interact to foster innovation (Reynolds \& Uygun, 2017). Innovation ecosystems are open, dynamic and network-based business environments, in which actors interact in complex ways, both competing and cooperating (Rabelo \& Bernus, 2015). As such, these environments encompass cyclical flows of tangible resources, such as human and financial, as well as intangible resources, such as information and knowledge (Shaw \& Allen, 2016).

To analyze and evaluate ecosystem resources, it is pertinent to use Resource Based View (RBV), which allows a better understanding of the specific differences and performance of each network (Fensterseifer \& Wilk, 2005), maximizing the potential of innovation. The RBV's central proposition is that the source of competitive advantage can be found in the resources and competencies developed and controlled by organizations (Barney, 1991; Dierickx \& Cool, 1989; Grant, 1991; Wernerfelt, 1984). However, according to Hansen, Perry, and Reese (2004), what an organization does with its resources is as important as the resources themselves.

The resource orchestration approach emerges with the proposal to highlight the way in which the use of these resources occurs. This perspective expands the RBV theory by explicitly considering the role of managers' activities in potential of strategic resources (Sirmon, Hitt, Ireland \& Gilbert, 2011). This recent development of RBV has demonstrated the need for organizations to better orchestrate - or coordinate - their resources (Sirmon, Hitt \& Ireland, 2007; Maritan \& Peteraf, 2011). The perspective of the orchestration of resources establishes three areas of analysis in organizations: the amplitude of the companies (scope of the company), depth (levels of hierarchy) and life cycle (stage of maturity). Sirmon et al (2011) argue that breadth, depth and life cycle affect how managers handle company resources to maximize the feasibility of achieving a competitive advantage. Sirmon et al. (2007) also developed a resource management structure that focused on managers' actions. The authors defined resource management as the comprehensive process of structuring, grouping and leveraging company resources with the aim of creating value for customers and competitive advantages for the company. 
A successful innovation ecosystem is the result of a process of continuous evolution, which is often long, complex and slow (Rabelo \& Bernus, 2015) and its development may have different stages of maturity (Gomes et al., 2016). The maturity stage has an indirect effect on innovation (Koberg et al., 1996; Westerman et al., 2006), encompassing several characteristics that influence it, such as uncertainty (Semadeni \& Anderson, 2010), size (King et al., 2003), age (Kotha et al., 2011) and experience (Godart et al., 2015). Given this scenario, the present paper seeks to answer the following question: How are resources orchestrated to generate innovation in innovation ecosystems? To answer this question, qualitative exploratory research was conducted in two innovation ecosystems in different stages of development: 4th District, in Porto Alegre (emergence) and Porto Digital, in Recife (growth). Both ecosystems have similar objectives, such as revitalizing a geographic space with economic potential and fostering innovation in key areas, linked mainly to the creative industries and to the information and communication technology.

This research is justified since it seeks to fill two theoretical gaps such as the discussion of how to orchestrate resources at the ecosystem level and the comparison between different stages of development. Although the literature on orchestration of networks is growing, it is still considered incipient and fragmented (Hurmelinna-laukkanem \& Natti, 2018; Nilsen \& Gausdal, 2017). While studies have focused on what the links are between resource shortages and lack of growth, there is an important gap in how these resources are acquired and coordinated (or orchestrated) to achieve growth (Wright, Clarysse \& Mosey, 2012). If the theme is already incipient when it comes to companies, regarding ecosystems it is practically nonexistent. Another point that is not considered in many orchestration studies is the stage of development of the ecosystem (Bittencourt et al. 2018). It is understood that according to the stage of development, the network presents a set of characteristics that interfere on its innovation and its relations with the resources. This way, recently, the greater interest and discussion in the literature have been dedicated to the network life-cycle (Fornahl, Hassink \& Menzel; 2015). It was also identified that the orchestration changes according with the stage of development (Nielsen \& Gausdal, 2017).

This article is divided into four parts in addition to this introduction. Following, the theoretical framework that supported the research will be addressed: innovation ecosystems and resource orchestration. Next are the methodological procedures used. After, the data analysis is presented, followed by the discussion of the results. Finally, we discuss the final considerations of the study. 


\section{Resource orchestration in innovation ecosystems}

\subsection{Innovation ecosystems}

The innovation ecosystem approach emphasizes precepts of natural systems that resemble what happens in business environments, such as the connections and dynamics of evolution, competition, predation and mutualism among their actors (Shaw \& Allen, 2016). The term "ecosystem", originating from biology, was first associated with business by Moore (1993), but only became popular in the 2010s, being mainly linked to entrepreneurship (Isenberg, 2010; Stam, 2015) and to innovation (Autio \& Thomas, 2014). Since then, the term has gained ground in academic discussions. Most recent articles have been addressing more specific topics such as open innovation (Robaczewska, Vanhaverbeke, \& Lorenz, 2019), the role of universities (Heaton, Siegel, \& Teece, 2019; Thomas, Faccin, \& Asheim, 2020), and smart specialization (Lopes et al., 2020) in different configurations of innovation ecosystems.

In this perspective, an innovation ecosystem is composed by a set of interdependent actors with conflicting technical, social, economic, and political interests, but also with converging goals, priorities, expectations, and behaviors that cooperate and compete concomitantly in a specific geographical location. Thus, innovation ecosystems are hybrids of different networks and systems with fractal, multilevel, multimodal, multinodular, and multilateral configurations, with tangible and intangible resources designed to promote innovation in a territory (Carayannis, Grigoroudis, Campbell, Meissner \& Stamati, 2018). Such environments have several elements.

Components of innovation ecosystems include: infrastructure, regulations, financial capital, knowledge, ideas, interface between actors, architectural principles (Rabelo \& Bernus, 2015), companies, consumers, suppliers, regulators (Gomes et al., 2016), entrepreneurs, workers, investors, mentors, universities and an entrepreneurial culture that encourages risktaking (Spigel, 2015). Therefore, in innovation ecosystems, different actors must interact, collaborate and play complementary roles in order to cocreate value (Thomas et al., 2018) and produce innovation. These actors can be classified according to the quadruple helix model (Arnkill, 2010; Carayannis \& Campbell, 2009; Carayannis et al., 2018).

Helix approaches emphasize the importance of interaction between academia, companies and government - entities that form the triple helix -, in addition to civil society the fourth helix - for the capture and delivery of economic and social value (Cavallini et al., 2016). While the triple helix model highlights the interrelationships and the transformation in the role of the actors from the production side, i.e., state, corporations and academia in 
innovation (Etzkowitz \& Leydersdorff, 1995), the quadruple helix model brings out the importance of the users' side, represented by civil society. A more recent approach is that of the quintuple helix model, which focuses especially on the environment as the fifth helix and issues related to sustainability (Carayannis et al., 2018). For the purpose of this study, we consider the quadruple helix model, given it relates to the four groups of actors that produce innovation in an ecosystem.

According to the quadruple helix model, innovation is the outcome of the interplay between academia, government, companies, and society (Carayannis \& Campbell, 2009). For the success of an innovation ecosystem, the four groups of actors must be engaged in innovation processes and in the creation of a clear (Thomas \& Autio, 2020) and comprehensive value proposition (Walrave et al., 2018). The quadruple helix also emphasizes the importance of collaboration, as it encourages the creation, diffusion, and application of new knowledge, thereby resulting in new ideas, technologies, and innovation (Cavallini et al., 2016). However, for collaboration to happen, actors must align their collective and individual interests, a complex task that depends on the various processes that occur within the innovation ecosystems.

Thus, it is necessary to understand, from an evolutionary and dynamic perspective, how innovation ecosystems develop over time and adapt to new contextual configurations (Spigel \& Harrison, 2017). A successful innovation ecosystem is the result of a process of continuous evolution, that is often long, complex and slow (Rabelo \& Bernus, 2015) and its development may have different stages of maturity (Gomes et al., 2016). Possibly the different stages of maturity influence in different ways for innovations to occur in ecosystems.

However, further studies are needed to describe how the emergence and development of an innovation ecosystem occurs (Bittencourt \& Figueiró, 2019). For Rabelo and Bernus (2015), these phases are "analysis", in which the decision to create the ecosystem is made; "project" when architecture of the ecosystem is defined; implementation, through the recruitment of key actors, the dissemination and establishment of formal and infrastructure conditions for the ecosystem to operate; implementation, with ecosystem management activities; and conclusion, in which the ecosystem goes through a metamorphosis to survive and continue to develop or is decommissioned.

To search for models that deal with the stages of the ecosystem life cycle,the connection of this theme with the field of studies on geographic agglomerations was considered, having a close link with the literature of industrial clusters (Spigel \& Harrison, 2015). Thus, we opted 
for the stages proposed by Presutti et al. (2013). According to these authors, these geographical agglomerations are idiosyncratic and evolve over time, going through two stages: emergence and growth.

At the emergency stage, relations between local actors are transitory, fragmented and unstable; and the process of acquiring internal knowledge is almost nonexistent (Bittencourt $e t$ al. 2018). At the later stage of growth, a stock of knowledge develops and tacit knowledge evolves organically through localized practices. At this stage, there is a dynamic process of knowledge diffusion and sharing among actors (Presutti et al., 2013).

In summary, even if there are models to be tested empirically, further studies are needed on the life cycle stages of ecosystems on which are the processes involved in each stage and the sequence they occur (Rabelo \& Bernus, 2015). This study seeks to contribute to the still scarce literature on life cycle and maturity stages of innovation ecosystems (Moore, 1993; Piqué et al., 2019; Cantner, 2020), while analyzing the influence of resource orchestration on this process.

\subsection{Resource orchestration}

The competitive landscape in which most organizations operate has become highly complex and increasingly dynamic. Such context implies an uncertainty regarding the appropriate strategies to be implemented (Sirmon, 2011). Given that the primary pursuit of business is to create and maintain value (Conner 1991), the Resource Based View (RBV) theory argues that resources are responsible for value creation through the development of competitive advantage (Ireland, Hitt \& Sirmon, 2003). However, merely having these resources does not assure the development of competitive advantages or value creation (Barney \& Arikan, 2001; Priem and Butler, 2001). To realize value creation, companies must accumulate, combine and exploit resources (Grant, 1991; Sirmon \& Hitt, 2003). Thus, resource management is essential to value creation, because the way resources are used is, at least, as important as owning them (Penrose, 1959).

In this scenario comes the approach of resource orchestration. Such a perspective expands resource-based theory by explicitly considering the role of manager activities in achieving the potential of strategic resources (Sirmon, Hitt, Ireland, \& Gilbert, 2011). Thus, the dynamism of the environment and the role of the manager are among the factors that may explain the link between resource management and value creation (Sirmon et al., 2011). Thus, resource orchestration originates from a combination of two perspectives identified in the literature regarding the use of resources for competitive advantage: the resource management 
proposed by Sirmon et al. $(2007 ; 2011)$ and the asset orchestration proposed by Helfat et al. (2007). This takes into account not only the particularities of the organization, but also the dynamic environment in which it is inserted.

Sirmon et al. (2007) developed a resource management structure that focused on managers' actions. They defined resource management as the comprehensive process of structuring, grouping and leveraging company resources with the aim of creating value for customers and competitive advantages for the company. Each one of these three processes has three sub-processes. The structuring involves (1) the acquisition, (2) the accumulation and (3) the divestment of resources to form the company's resources portfolio. The grouping refers to the integration of resources to form resources, with three sub-processes: (1) stabilization, or small incremental improvements for existing resources; (2) enrichment, which expands current capabilities; and (3) pioneering spirit, which creates new capabilities.

Leverage involves a sequence of processes to explore the company's capabilities and take advantage of specific market opportunities; including (1) mobilization, which provides a plan or prospect for the resources needed to form essential capacity configurations; (2) coordination, which involves the integration of capacity configurations; and (3) deployment, where a resource advantage, market opportunity or business strategy is used to explore capacity configurations formed by the coordination sub-process. Although each process and its subprocesses are important, several different paths can be pursued in the resource management framework.

To deal with the uncertainty of competitive rivalry or fluctuations in demand, more and diverse resources may be needed to develop new capabilities that can be leveraged in response to change. (Sirmon et al., 2007). In other words, to create value and develop competitive advantages, it is necessary to synchronize processes (Sirmon et al., 2007). As a result, Sirmon et al (2011) integrate the perspectives of resource management (Sirmon et al., 2007) with the orchestration of assets (Helfat et al., 2007) in order to allow a more precise understanding of the managers' functions within the RBV.

Based on the literature presented, the categories to be analyzed were formulated, as presented in Table 1. 
Table 1 - Analysis dimensions

\begin{tabular}{|c|c|c|}
\hline $\begin{array}{c}\text { Analysis } \\
\text { Dimensions }\end{array}$ & Description & Authors \\
\hline Ecosystem Stage & Emergency or Growth & $\begin{array}{l}\text { Presutti et al. } \\
\text { (2013) }\end{array}$ \\
\hline Collective Resources & Key features of each ecosystem & Barney(1991) \\
\hline \multirow{3}{*}{$\begin{array}{l}\text { Dimensions of Resource } \\
\text { Orchestration }\end{array}$} & $\begin{array}{l}\text { Structuring (acquisition, accumulation and } \\
\text { divestment of resources) }\end{array}$ & \multirow{3}{*}{$\begin{array}{l}\text { Sirmon et al. } \\
\qquad(2007)\end{array}$} \\
\hline & $\begin{array}{l}\text { Grouping } \\
\text { (stabilization, } \\
\text { enrichment and pioneering spirit) }\end{array}$ & \\
\hline & $\begin{array}{l}\text { Leverage (mobilization, coordination } \\
\text { and implantation) }\end{array}$ & \\
\hline
\end{tabular}

Source: Elaborated by the authors.

In the context of this paper, resource orchestration is based on resource management and asset orchestration and focuses on how managers influence a resource-based competitive advantage. To explore this integration and develop a research agenda for resource orchestration, the ecosystem life cycle is also addressed. In the next section, the methodological procedures of the research will be presented.

\section{Methodological procedures}

The aim of this paper is to analyze how the process of orchestration of resources for the generation of innovations in innovation ecosystems occur. Therefore, a qualitative exploratory research was conducted, whose units of analysis were the innovation ecosystems of the 4th District, in Porto Alegre - RS and Porto Digital, in Recife - PE. For the selection of cases, we used the criterion of innovation ecosystems at different maturity stages: emergence (4th District) and growth (Porto Digital).

For data collection, the techniques of document analysis, non-participant observation and in-depth interviews were used. Observations took place at ecosystem events attended by their respective actors, such as lectures, meetings and workshops, and visits in loco. The indepth interviews were conducted with four experts in each ecosystem, observing the condition that each of the four helixes, i.e., government, society, academia, and companies should be represented by one expert, as shown in Table 2. One representative from each participating ecosystem sphere took part in the interview: universities, companies, government and society. 
Table 2 - Interviewee List

\begin{tabular}{|l|l|l|l|}
\hline \multicolumn{1}{|c|}{ Interviewee } & \multicolumn{1}{|c|}{$\mathbf{4}^{\mathbf{0}}$ District } & \multicolumn{1}{c|}{ Interviewee } & \multicolumn{1}{c|}{ Porto Digital } \\
\hline Interviewee 1 & $\begin{array}{l}\text { Municipal } \\
\text { Government }\end{array}$ & Interviewee 5 & $\begin{array}{l}\text { Government Support Center for } \\
\text { Creative Business }\end{array}$ \\
\hline Interviewee 2 & $\begin{array}{l}\text { Local } \\
\text { Cultural Centre }\end{array}$ & Interviewee 6 & Social Organization \\
\hline Interviewee 3 & University Professor & Interviewee 7 & University Professor \\
\hline Interviewee 4 & Local Businessman & Interviewee 8 & Local Businessman \\
\hline
\end{tabular}

Source: Elaborated by the authors.

Case analysis was based on the three processes established by Sirmon et al. (2011): structuring; grouping; and leverage and its subprocesses. After, the analyzed cases are presented, followed by the discussion of the study results.

\section{Results and discussion}

For this study the innovation ecosystems of the 4th District, in Porto Alegre (south of Brazil) and of Porto Digital, in Recife (north of Brazil) were selected. The 4th District (4D) is an ecosystem designed to become an innovation hub in the city. It already has several initiatives, most of them linked to information and communication technologies, creative industries, education and health. The 4D is located in an old industrial zone of Porto Alegre, currently degraded and presenting social ills. Despite its strategic location, at the intersection of several exits towards the neighboring areas and the city center, companies have gradually evaded this region due to a number of circumstances, including problems such as drug trafficking, theft and prostitution, but also due to the provision of a number of benefits at other industrial centers, such as tax benefits, lower costs, and access to skilled labor (Bittencourt et al., 2018).

In Recife, Porto Digital (PD) is a widespread innovation ecosystem beyond its initial geographical delimitation in the old Recife neighborhood. Emerging from a local vocation for information technology, the development of PD has been encouraged and nurtured by government entities since the early 2000s and, since then, the ecosystem has been recognized three times, the last in 2015, as Brazil's best technology park (Startupi, 2015). Regarding the 4th District, it is possible to notice that in the structuring phase the acquisition of resources emerges from the exchanges and interactions between agents. From this, an integrated action between government and companies was identified to seek human, financial and physical resources for the ecosystem. Government agencies are seeking resources from the federal government and international organizations, as stated by Interviewee 1. In addition, another 
movement observed are business-to-business meetings to structure investments for the ecosystem.

Although the articulation of the 4th District ecosystem is not recent, the fact that it is still in an emergency period means that the agglomeration is still beginning this structuring phase, still presenting few actions regarding the resource accumulation and divestment subprocesses. The emergence phase is difficult to identify, but it is at this stage that both the foundation and the growth process are formed (Menzel \& Fornahl, 2010). The fact that the actors are unaware of the potentialities and limitations of the others involved makes the appropriation of ecosystem resources impossible to occur. It is worth highlighting that the meetings promoted by civil society organizations and ecosystem outreach materials developed by the municipal government serve as a means of concentrating and disseminating global resources to the ecosystem. To call such actors for action, it is necessary to have motivating factors and the construction of a well-designed planning to mobilize them (Dhanaraj \& Parkhe, 2006).

\begin{abstract}
Thus, resource pooling is still incipient in relation to the improvement of existing resources, because the ecosystem is still at the moment of resource structuring. However, it is clear that the foundation is already being built for stabilization, enrichment and pioneering to happen. For example, the mobilization to capture partners and international knowledge that the ecosystem has been doing: the participation of American researcher, Spanish university and the German government. Thus, the actors involved in an emergence stage play a vital role, given that they must be able to use favorable preconditions (Henning et al., 2013), local triggers and the policy framework, as well as putting into practice regional strategies for the ecosystem, promoting actions that improve collaboration between actors and the adjustment of national and regional policies (Yoon, 2017).
\end{abstract}

After this consolidation, it will be possible to leverage ecosystem resources. From the observations, it was possible to realize that although there is pride and willingness to participate in the formation of this ecosystem, the 4th District does not exhibit a unique identity. There is knowledge regarding the various initiatives, but it is not possible to perceive them entirely, that is, in an integrated and holistic way. Because of what was previously mentioned, Interviewee 2 states that a survey of all actions developed in the region is being made to be shared with all actors. Fundamentally, the creation and transfer of knowledge refers to the sharing that is acquired and implanted in the ecosystem (Gomes, 2016).

An attempt to consolidate and leverage resources was the elaboration of the ecosystem MasterPlan, a planning tool designed to assist in the coordination of 4D and an important dimension of orchestration. It is identified that the role of orchestrator of the 4th District ecosystem is decentralized, and the actions are developed according to the knowledge and skill of each actor. "Our meetings have been increasing the number of people exponentially," says 
Interviewee 4. The role of entrepreneurs and society ends up being paramount on community engagement. In addition, the city hall eventually becomes a protagonist on searching for strategic partners and financial resources. Finally, universities and collaborative houses act as knowledge disseminators. Thus, it is possible to acknowledge the effects of collaboration on the interplay among the quadruple helix actors. Collaboration encourages the creation, diffusion, and application of new knowledge and ultimately lead to the creation of economic and social value through innovation (Cavallini et al., 2016).

This engagement of different actors is associated with the notion of social connection that comprises the number and quality of social interactions that people have (Lancee \& Radl, 2012), involving the quality and the number of connections that one has with other people (Quigley \& Thornley, 2011). This process of increasing the number of actors involved and strengthening the connections between them shows that the network is consolidating (Menzel \& Fornahl, 2010).

In summary, based on the processes defended by Helfat et al. (2007), it is understood that the ecosystem of the 4th District is being structured with regard to the process of searching and selecting resources, with actions being developed by its most different actors. AS to the configuration and implementation of resources, the process is still incipient, and thus requires a pondering of actions. This step involves the process of acquiring, accumulating and divesting resources to form the portfolio (Helfat et al.; 2007). This stage can be visualized once we realize that the actors are still mapping and analyzing the resources available in the ecosystem.

On the other hand, in Porto Digital, the structuring phase also features many interactions and exchanges of knowledge, information and other tangible and intangible assets among the actors. In PD, it is observed that all actors are integrated in the search for resources for the ecosystem. According to the Interviewee 7 report, this prospecting is usually coordinated by the Porto Digital Management Center (NGPD), that is an entity created to strengthen the articulation between the actors and allocate public resources to stimulate the activities and demands of universities and companies in key-segments of the ecosystem. In PD, the organic articulation between entrepreneurs, the events promoted by the NGPD, and the fact that it is an urban and open ecosystem where all actors can easily meet or even run into each other, is fundamental. This enables interactions to occur more frequently and resource to flow more naturally. These relationships are in line with the definition of ecosystem defended by Jacobides et al. (2018) "the ecosystem is conceived as an economic community of interactive actors that 
affect each other through their activities, considering all relevant actors beyond the limits of a single industry."

Unlike 4D, in Porto Digital the pooling of resources is already well developed and improvements are being made to existing resources such as the revitalization of historic buildings to house creative business support infrastructure (e.g., Porto Media) and innovation (Jump accelerator and prototyping laboratories). Thus, it is clear that the ecosystem has already surpassed the phase of resource structuring and has some stability. Still, it is observed that the enrichment of these resources and the pioneering spirit in some areas stand out. Noteworthy are the innovations that emerge in the Information Technology (IT) and Creative Economy sectors, the latter driven mainly by the improvements made in infrastructure for games, audiovisual, prototyping and experimentation, among others. It is important to note that as instruments such as patents, copyrights and trademarks are developed, trust between actors is strengthened (Sakakibara, 2002; Teece, 2000).

It can be interpreted that Porto Digital's innovation ecosystem is at an advanced stage of leverage (as proven by the awards of best technology park in Brazil), after all, it is possible to verify that there is a plan for the application of resources and that program gaps in the ecosystem are also being filled, as explained by Interviewee 5. In addition, there is high capacity for coordination of resources in Porto Digital, mainly from the actions of the NGPD, including the universities and companies, which articulate with each other on fostering the ecosystem. This way, the role of orchestrator at Porto Digital is played by the NGPD; primarily responsible for joining efforts among different actors and leading actions in the ecosystem. The orchestrator also monitors and controls the knowledge flow and has a huge number of connections that are willing and able to provide it with important opportunities and resources (Cinelli, Ferraro \& Iovanella, 2019)

Therefore, a great articulation between the initiatives and the interests of the different actors is contemplated. Thus, the primary role of ecosystem government is to provide the necessary conditions and support for actions relating to ecosystem development. On the other hand, universities are the main source of qualified human capital for the ecosystem - added to promoting events of integration between actors - and entrepreneurs are kind of a link with the community and knowledge transfer as the point of execution, which means that, those that implement actions aim to result in innovations in the priority areas of the ecosystem. It is important to note that universities are considered important infrastructures that sustain 
innovation ecosystems and, at the same time, institutional mechanisms that stimulate local and regional development (Bittencourt et al., 2020)

Table 3 summarizes the comparison between the 4th District and Porto Digital innovation ecosystems.

Table 3 - Summary of Comparison between Ecosystems

\begin{tabular}{|l|l|l|}
\hline \multicolumn{1}{|c|}{ Dimensions } & \multicolumn{1}{c|}{$\mathbf{4}^{\mathbf{0}}$ District } & \multicolumn{1}{c|}{ Porto Digital } \\
\hline Ecosystem Stage & Emergency & Growth \\
\hline Collective Resources & $\begin{array}{l}\text { Events and spaces for } \\
\text { interaction between actors }\end{array}$ & $\begin{array}{l}\text { Knowledge, events and } \\
\text { Support Infrastructure }\end{array}$ \\
\hline $\begin{array}{l}\text { Steps for Resource } \\
\text { Orchestration }\end{array}$ & Structuring & Leverage \\
\hline Orchestrator & Decentralized & NGPD \\
\hline
\end{tabular}

Source: Elaborated by the authors.

The 4th District seeks to develop a trajectory similar to Porto Digital, since its main objectives are the revitalization of a degraded area and with great potential for local socioeconomic development, by encouraging entrepreneurship and innovation. The 4th District is characterized as an ecosystem in an emergency phase, for the ties between local actors are tenuous and the relations between them are still transitory, fragmented and unstable. Similarly, at this early stage, due to the lack of proximity and articulation between actors and other elements, the acquisition of knowledge within the ecosystem is almost nonexistent. For Brenner and Muhlig (2007), the emergence of a local network is only possible if the relevant factors and characteristics (prerequisites) are sufficiently provided in the region.

On the other hand, Porto Digital has a longer, solid and consistent trajectory, which characterizes it as a growing innovation ecosystem. Through the collected data, it is noticed a great articulation between the actors and initiatives encompassed by this technology park. Due to this maturity and the formal and informal interactions between actors, knowledge spreads more organically, and tacit knowledge, specifically, flows more easily between actors, generating the sharing culture characteristic of this stage, as proposed by Presutti et al. (2013).

In both ecosystems, the key strategic resources are knowledge - especially academic and the supporting infrastructure for innovation. However, in PD the fact that there is an orchestrating actor, as is the NGPD - appears to be one of the competencies that favor the orchestration of resources and consequently the development of the ecosystem and possibly a greater chance for innovations to emerge. Orchestration comprises different activities for formulating the network and directing and managing the practices and processes so as to enable 
value creation and capture (Batterink et al., 2010). It is about a set of evolving actions, not a static structural position (Paquin \& Howard-Grenville, 2013).

Regarding the orchestration of resources, it is possible to notice that, in the structuring phase, both ecosystems use the exchanges that occur between the actors for the acquisition of resources. However, due to its more consolidated trajectory and the advanced stage of ecosystem maturity, the PD presents this in a more structured way, taking advantage of the government's integration with companies, academia and society, as well as the formal and informal interactions between them. the actors - especially the entrepreneurs. This way, the accumulation and divestment subprocesses are even more incipient in the 4th District innovation ecosystem and more developed in the PD.

In the bundling phase, equally, the PD ecosystem is also more developed, as it is already stabilized - in relation to its own resources and the actions and initiatives that the ecosystem performs - enriching what is already done and pioneering in several areas. From this, some startups are already emerging in the national and international scenarios for their innovative technologies in the creative and information and communication technology (ICT) segments. In this same phase, the ecosystem of the 4th District has been advancing, but there are still few possibilities for resources to be improved, since they are still scarce.

Thus, while the PD ecosystem is already mature enough for the leverage stage, in which the mobilization, coordination and deployment of resources occur, this are sub-processes that can be conducted by the main ecosystem orchestrator (NGPD), the 4th District that still needs to overcome the structuring stage in order to have the necessary resources to be stabilized, improved, coordinated and implemented, having greater potential to generate innovations (Sirmon et al., 2011).

From this, according to the analyzes performed, a direct relationship was identified between the dimensions of resource orchestration and the stage of ecosystem development. That is, it is understood that, as the resources of the ecosystem are being orchestrated, it is possible that it changes the stage of development and, thus, enhances the innovation generated. The following is Figure 1, with the Framework for Orchestrating Resources in Ecosystems. 
Figure 1 - Framework of orchestration of resources in ecosystems

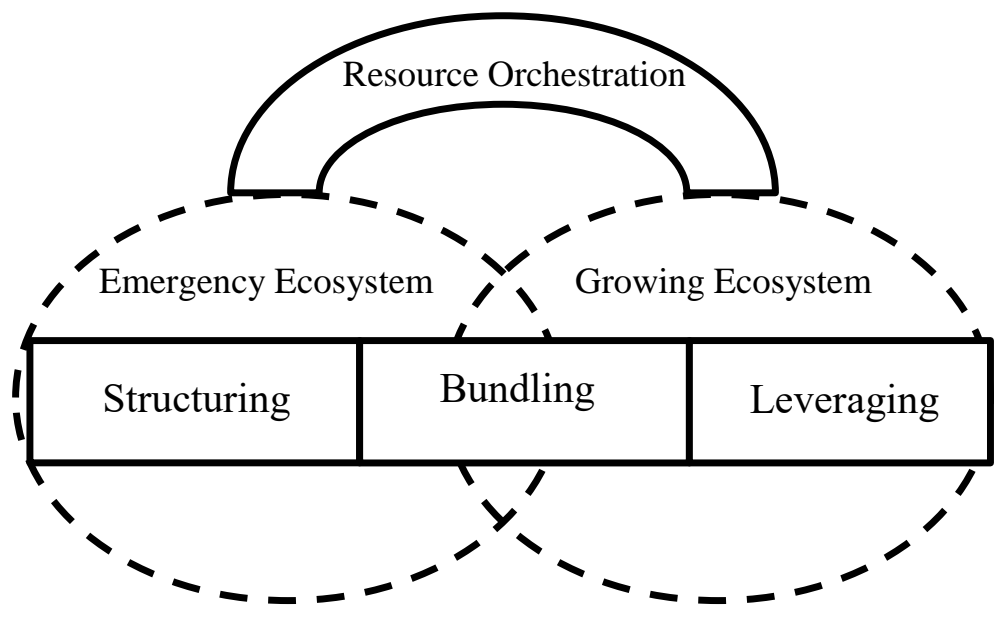

Source: Elaborated by the authors.

It is proposed that the orchestration of resources in ecosystems occurs according to the three phases suggested by Sirmon (2007), which are: structuring, bundling and leverage. Based on the studied cases, it is observed that emergent ecosystems may present more orchestration characteristics of the early phases (structuring and bundling), whereas in more consolidated ecosystems, already in growth, the orchestration of resources possibly happens with more emphasis in the transition from the grouping stage to the leverage stage or the leverage stage only.

It can be inferred that a point of change from the stage of development emergency to growth would be the beginning of resource leverage, that is, once articulated, they begin to generate innovations for organizations and the environment in which the ecosystem is inserted. In a way, it is in line with the one proposed by Presutti et al., 2013 regarding the interactions in the actors for value generation. However, the bundling dimension is added as an intermediate of this process. It is emphasized that this is an exploratory research and, therefore, it is advisable to apply a confirmatory study to verify these findings.

\section{Final remarks}

Ecosystems can be considered a set of tangible and intangible resources that, together, foster innovation. In the past, managerial and academic discussions focused on obtaining resources; nowadays, however, the biggest question is due to the way to coordinate them. From this, the present research aimed to understand how resources are orchestrated to generate innovation in innovation ecosystems. 
The two cases elected for this study - 4th District and Porto Digital - were analyzed through the dimensions of resource orchestration defended by Sirmon et al. (2011) and its subprocesses: structuring, bundling and leverage. From this, it can be inferred that projected enterprise dimensions are adaptable to ecosystems. In addition, it was found that these dimensions are directly linked to the development of the ecosystem, since the ecosystem of the 4th District was still in the process of structuring resources, incipient in bundling and virtually zero in terms of leverage.

As a second contribution, based on the experience of Porto Digital's growth stage, it is important to have a certain actor that plays the role of orchestrator in the ecosystem as it improves the use of resources (Heaton, Siegel \& Teece, 2019) and facilitates communication between all actors and the articulation among them. Thus, it is suggested that the ability to interact between different actors and transform resources into innovations are the main characteristics for the orchestrator's performance. A confirmatory study is needed to ratify this finding or to demonstrate that this may be an atypical and contextual condition.

Moreover, it was possible to verify the importance of the joint engagement of the quadruple helix actors, i.e., academia, companies, government, and society, for the development of the innovation ecosystem. Collaboration among them is a critical resource and can be improved through orchestration processes. In the Porto Digital ecosystem, collaboration is already being leveraged while in 4D it is still in the structuring phase, such as the ecosystem itself.

As general contributions to the literature, there is the emerging discussion about ecosystem resources, which becomes even more original as it seeks to understand how they are orchestrated. The use of the recent approach on resource orchestration also enables the present study contribute to the consolidation of this still incipient theme. In addition, an analysis framework on this problem was proposed; and the comparison between ecosystems of different stages of development broadens the discussion, bringing one more element. It was found a direct relationship between the time of agglomeration with resource coordination and, therefore, the results of innovation.

As social contributions, we believe that this paper helps public managers to identify the stage of development of the innovation ecosystem and perform more assertive public policies. Moreover, the ecosystem and organizations managers are able to better orchestrate their resources according to the stage of development. We know the complexity of ecosystem orchestration; however, we understand that framework and discussions carried out by this 
research bring important contributions for orchestrators and ecosystem participants to maximize the innovations generated.

Finally, the study was limited to research in only two ecosystems and with few interviews in each. As future studies, a survey with a larger number of participants, and cases, is suggested. A longitudinal study in an ecosystem is believed to be relevant to better understand the process of resource orchestration over time, as well as to comprehend the role of the orchestrator. It is also suggested to conduct quantitative studies linking orchestrator, orchestration of resources, acquired resources, stage of development and innovation results.

\section{References}

Arnkil, R., Järvensivu, A., Koski, P., \& Piirainen, T. (2010). Exploring the quadruple helix. Report of quadruple helix research for the CLIQ project. Tampere: Work Research Centre, University of Tampere.

Autio, E.; Thomas, L. Innovation ecosystems. (2014) The Oxford handbook of innovation management, p. 204-288, 2014.

Bardin, L. (1977) Análise de conteúdo. Lisboa: Edição 70.

Barney, J. B. Firm Resources and Sustained Competitive Advantage. (1991) Journal of Management,v. 17, n. 1, p. 99-12.

Barney, J. (1991). Firm resources and sustained competitive advantage. Journal of management, 17(1), 99-120.

Barney, J. B., \& Arikan, A. M. (2001). The resource-based view: Origins and implications. The Blackwell handbook of strategic management, 124-188.

Batterink, M. H., Wubben, E. F., Klerkx, L., \& Omta, S. W. F. (2010). Orchestrating innovation networks: The case of innovation brokers in the agri-food sector. Entrepreneurship and regional development, 22(1), 47-76.

Bittencourt, B. A.; Figueiró, P. S. (2019). Innovation ecosystems articulation and shared value creation. Cadernos EBAPE.BR, v. 17, n. 4, 2019.

Bittencourt, B. A.; Zen, A. C.; Santos, D. A. G. (2020). Orchestrating university innovation ecosystem: the case of brazillian university. Revue Internationale d'Intelligence Economique - R2IE. V 11 69-95.

Bittencourt, B.A., Zen, A.C., Schmidt, V. and Wegner, D. (2018), The orchestration process for emergence of clusters of innovation, Journal of Science and Technology Policy Management, Vol. 0 No. 0, null, doi: 10.1108/JSTPM-02-2018-0016. 
Brenner, T. and Mühlig, A. (2007), "Factors and mechanisms causing the emergence of local industrial clusters - a Meta-Study of 159 cases", Papers on Economics and Evolution, \#0723, MPI of Economics.

Cantner, U., Cunningham, J. A., Lehmann, E. E., \& Menter, M. (2020). Entrepreneurial ecosystems: a dynamic lifecycle model. Small Business Economics, 1-17.

Carayannis, E. G., \& Campbell, D. F. (2009). 'Mode 3' and 'Quadruple Helix': toward a 21st century fractal innovation ecosystem. International journal of technology management, 46(3-4), 201-234.

Carayannis, E. G., Grigoroudis, E., Campbell, D. F., Meissner, D., \& Stamati, D. (2018). The ecosystem as helix: an exploratory theory-building study of regional co-opetitive entrepreneurial ecosystems as Quadruple/Quintuple Helix Innovation Models. $R \& D$ Management, 48(1), 148-162.

Cavallini, S., Soldi, R., Friedl, J., Volpe, M., 2016. Using the quadruple helix approach to accelerate the transfer of research and innovation results to regional growth.

Choi, H., Kim, S. H., \& Lee, J. (2010). Role of network structure and network effects in diffusion of innovations. Industrial marketing management, 39(1), 170-177.

Cinelli M, Ferraro G.;I and Iovanella A. (2019). Network processes for collaborative innovation. International Journal of Entrepreneurship and Small Business 36(4):430-452 10.1504/IJESB.2019.10011453.

Conner, K. R. (1991). A historical comparison of resource-based theory and five schools of thought within industrial organization economics: do we have a new theory of the firm?. Journal of management, 17(1), 121-154.

Creswell, J. (2010) W. Projeto de pesquisa métodos qualitativo, quantitativo e misto. In: Projeto de pesquisa métodos qualitativo, quantitativo e misto. Artmed.

Dhanaraj, C. and Parkhe, A. (2006), "Orchestrating innovation networks", Academy of Management Review, Vol. 31 No. 3, pp. 659-669.

Dierickx, I., \& Cool, K. (1989). Asset stock accumulation and sustainability of competitive advantage. Management science, 35(12), 1504-1511.

Etzkowitz, H., \& Leydesdorff, L. (1995). The Triple Helix--University-industry-government relations: A laboratory for knowledge based economic development. EASST review, 14(1), 14-19.

Etzkowitz, H., \& Leydesdorff, L. (2000). The dynamics of innovation: from National Systems and "Mode 2" to a Triple Helix of university-industry-government relations. Research policy, 29(2), 109-123.

Fensterseifer, J. E., \& Wilk, E. D. O. (2005). Visão da firma baseada em recursos, clusters e performance: um estudo no setor vitivinícola do RS. Anais do Encontro Nacional da Associação Nacional de Pós-Graduação e Pesquisa em Administração. 
Fornahl, D., R. Hassink and M.P. Menzel (2015), 'Broadening our knowledge on cluster evolution', European Planning Studies, 23 (10), 1921-31.

Gomes, L. A. V. et al. (2016) Unpacking the innovation ecosystem construct: Evolution, gaps and trends. Technological Forecasting and Social Change.

Grant, R. M. (1991). The resource-based theory of competitive advantage: implications for strategy formulation. California management review, 33(3), 114-135.

Hair, J. et al. (2005) Fundamentos de métodos de pesquisa em administração. Bookman Companhia Ed, 2005.

Hansen, M. H., Perry, L. T., \& Reese, C. S. (2004). A Bayesian operationalization of the resource-based view. Strategic Management Journal, 25(13), 1279-1295.

Heaton, S., Siegel, D. S., \& Teece, D. J. (2019). Universities and innovation ecosystems: a dynamic capabilities perspective. Industrial and Corporate Change, 28(4), 921-939.

Helfat, C. E.; Peteraf, M. A. Understanding dynamic capabilities: Progress along a developmental path. (2009) Strategic Organization, v. 7, n. 1, p. 91-102.

Helfat, C.; Finkelstein, S.; Mitchell, W.; Peteraf, M.; Singh, H.; Teece, D.; Winter, S. (2007). Dynamic Capabilities: Understanding Strategic Change in Organizations. Malden, MA: Blackwell.

Henning, M., Stam, E. and Wenting, R. (2013), "Path dependence research in regional economic development: cacophony or knowledge accumulation?", Regional Studies, Vol. 47 No. 8, pp. 1348-1362.

Hurmelinna-Laukkanen, P., \& Nätti, S. (2018). Orchestrator types, roles and capabilities - A framework for innovation networks. Industrial Marketing Management, 74, 65-78. https://doi.org/10.1016/j.indmarman.2017.09.020 September 2017.

Hurmelinna-Laukkanen, P.; Nätti, S. (2012) Network Orchestration for Knowledge Mobility - The Case of an International Innovation Community. Journal of Business Market Management, v. 5, n. 4, p. 244-264.

Isenberg, D. J. (2010) How to start an entrepreneurial revolution. Harvard business review, v. 88 , n. 6 , p. $40-50$.

Jacobides, M. G., Cennamo, C., \& Gawer, A. (2018). Towards a theory of ecosystems. Strategic Management Journal, 39(8), 2255-2276.

King, D.R., J.G. Covin, and W. H. Hegarty. 2003. Complementary resources and the exploitation of technological innovations. Journal of Management 29(4): 589-606.

Koberg, C. S., Uhlenbruck, N., \& Sarason, Y. (1996). Facilitators of organizational innovation: The role of life-cycle stage. Journal of business venturing, 11(2), 133-149. 
Kotha, R., Zheng, Y., \& George, G. (2011). Entry into new niches: The effects of firm age and the expansion of technological capabilities on innovative output and impact. Strategic Management Journal, 32(9), 1011-1024.

Lancee, B., Radl, J. (2012). Social connectedness and the transition from work to retirement. The Journals of Gerontology, Series B: Psychological Sciences and Social Sciences. v.67, n.4, p. 481-490. 2012.

Lopes, J., Farinha, L., \& Ferreira, J. J. (2020). Regional Innovation Ecosystems and Smart Specialization: Opportunities and Challenges For Regions. Revista Brasileira de Gestão e Desenvolvimento Regional, 16(1).

Lumineau, F., Oliveira, N. (2018). A pluralistic perspective to overcome major blind spots in research on interorganizational relationships. Academy of Management Annals, 12: 440465 .

Mack, E.; Mayer, H. (2016) The evolutionary dynamics of entrepreneurial ecosystems. Urban Studies, v. 53, n. 10, p. 2118-2133.

Majchrzak, A., Jarvenpaa, S. L., \& Bagherzadeh, M. (2015). A review of interorganizational collaboration dynamics. Journal of Management, 41: 1338-1360.

Maritan, C. A., \& Peteraf, M. A. (2011). Invited editorial: Building a bridge between resource acquisition and resource accumulation. Journal of Management, 37(5), 1374-1389.

Mason, C.; Brown, R. (2014) Entrepreneurial ecosystems and growth oriented entrepreneurship. Final Report to OECD, Paris, v. 30, n. 1, p. 77-102.

Menzel, M. P.; Fornahl, D. (2010). Cluster life cycles-dimensions and rationales of cluster evolution. Industrial and Corporate Change, v. 19, n. 1, p. 205-238.

Moore, J. F. (1993). Predators and prey: a new ecology of competition. Harvard business review, 71(3), 75-86.

Nambisan, S.; Sawhney, M. (2011) Orchestration Processes in Network-Centric Innovation: Evidence From the Field. Academy of Management Perspectives.

Nilsen, E. R., \& Gausdal, A. H. (2017). The Multifaceted Role of The Network Orchestrator - A Longitudinal Case Study. International Journal of Innovation Management, 0(0).

Paquin, R. L., \& Howard-Grenville, J. (2013). Blind dates and arranged marriages: Longitudinal processes of network orchestration. Organization Studies, 34(11), 1623-1653.

Penrose, E. (1959). The Theory of the Growth of the Firm. Oxford University Press.

Pikkarainen, M., Ervasti, M. and Hurmelinna-Laukkanen Nätti, S. (2017), "Orchestration roles to facilitate networked innovation in a healthcare ecosystem", Technology Innovation Management Review, Vol. 7 No. 9, pp. 30-43. 
Pique, J.M., Miralles, F. \& Berbegal-Mirabent, J. (2019). Areas of Innovation in Cities: The evolution of 22@Barcelona. International Journal of Knowledge-Based Development, $10(1), 43-74$

Presutti, M.; Boari, C.; M., (2013) Antonio. Inter-organizational geographical proximity and local start-ups' knowledge acquisition: a contingency approach. Entrepreneurship \& Regional Development, v. 25, n. 5-6, p. 446-467.

Priem, R. L., \& Butler, J. E. (2001). Is the resource-based "view" a useful perspective for strategic management research?. Academy of Management Review, 26(1), 22-40.

Quigley, R., \& Thornley, L. (2011). Literature review on community cohesion and community severance: Definitions and indicators for transport planning and monitoring. Wellington: Quigley and Watts Ltd.

Rabelo, Ricardo J.; Bernus, Peter. (2015) A holistic model of building innovation ecosystems. IFAC-PapersOnLine, v. 48, n. 3, p. 2250-2257.

Ramadani, V., Grguri, S., Rexhepi, G. and Abduli, S. (2013) "Innovation and Economic Development: The Case of FYR of Macedonia", Journal of Balkan and Near Eastern Studies, Vol. 15, issue 3, pp. 324- 345, doi: 10.1080/19448953.2013.789326.

Reynolds, E. B.; Uygun, Y. (2017). Strengthening advanced manufacturing innovation ecosystems: The case of Massachusetts. Technological Forecasting and Social Change.

Reypens, C., Lievens, A., \& Blazevic, V. (2019). Hybrid Orchestration in Multi-stakeholder Innovation Networks: Practices of mobilizing multiple, diverse stakeholders across organizational boundaries. Organization Studies. https://doi.org/10.1177/0170840619868268.

Rinkinen, S.; Harmaakorpi, V. (2017) The business ecosystem concept in innovation policy context: building a conceptual framework. Innovation: The European Journal of Social Science Research, p. 1-17.

Ritala, P.; Hurmelinna-Laukkanen, P.; Nätti, S. (2012). Coordination in innovation-generating business networks - the case of Finnish Mobile TV development. Journal of Business \& Industrial Marketing, 27, 324-334.

Robaczewska, J., Vanhaverbeke, W., \& Lorenz, A. (2019). Applying open innovation strategies in the context of a regional innovation ecosystem: The case of Janssen Pharmaceuticals. Global Transitions, 1, 120-131.

Sakakibara, M. (2002). Formation of R\&D consortia: Industry and company effects. Strategic Management Journal [on-line], [S.1.], v. 23, n. 11, p. 1033-1050.

Sampieri, R. H.; Collado, C. F.; Lucio, M. P. B. (2013) Métodos de Pesquisa, 5. ed. Porto Alegre: Penso.

Semadeni, M., \& Anderson, B. S. (2010). The follower's dilemma: Innovation and imitation in the professional services industry. Academy of Management Journal, 53(5), 1175-1193. 
Shaw, D. R.; Allen, T. (2016) Studying innovation ecosystems using ecology theory. Technological Forecasting and Social Change, 2016.

Sirmon, D. G.; Hitt, M. A., Ireland, R. D. (2007). Managing firm resources in dynamic environments to create value: Looking inside the black box. Academy of Management Review, v. 32, n. 1, p. 273-292.

Sirmon, D. G.; Hitt, M. A.; Ireland, D. R.; Gilbert, B. A. (2011) Resource Orchestration to Create Competitive Advantage: Breadth, Depth, and Life Cycle. Effects. Journal of Management, v. 37, n. 5, p. 1390-1412.

Spigel, B. (2017) The relational organization of entrepreneurial ecosystems. Entrepreneurship Theory and Practice, v. 41, n. 1, p. 49-72.

Spigel, B; Harrison, R. (2017) Toward a process theory of entrepreneurial ecosystems. Strategic Entrepreneurship Journal. p. 1-18.

Stam. (2015) Entrepreneurial ecosystems and regional policy: a sympathetic critique. European Planning Studies, v. 23, n. 9, p. 1759-1769, 2015.

STARTUPI, (2015).Porto Digital é eleito o melhor parque tecnológico do Brasil Disponível em: https://startupi.com.br/2015/12/porto-digital-e-eleito-o-melhor/. Acesso em $10 \mathrm{dez}$ 2017.

Teece, D. J. (2000). Managing intellectual capital: organizational, strategic, and policy dimensions. London: Oxford University Press.

Thomas, E., Faccin, K., \& Asheim, B. T. (2020). Universities as orchestrators of the development of regional innovation ecosystems in emerging economies. Growth and Change.

Thomas, L.D., Autio, E., (2020). Innovation ecosystems in management: an organizing typology. In: Oxford Research Encyclopedia of Business and Management.

Valkokari, K., Seppanen, M. M. and Jylha-Ollila, S. (2017). Orchestrating innovation ecosystems: a qualitative analysis of ecosystem positioning strategies. Technology Innovation Management Review. V3. 12-24.

Wernerfelt, B. (1984). A resource-based view of the firm. Strategic Management Journal, 5(2), 171-180.

Westerman, G., McFarlan, F. W., \& Iansiti, M. (2006). Organization design and effectiveness over the innovation life cycle. Organization Science, 17(2), 230-238.

Wright, M., Clarysse, B., Lockett, A., and Knockaert, M., (2008). 'Mid-range Universities' Linkages with Industry: Knowledge Types and the Role of Intermediaries,' Research Policy, 37, 1205-1223.

Yoon, D. (2017), "The regional-innovation cluster policy for R\&D efficiency and the creative economy: with focus on DaedeokInnopolis", Journal of Science and Technology Policy Management, Vol. 8 No. 2, pp. 206-226. 